\title{
MiHAELA KOLETNIK
}

\section{SAMOSTALNIŠKE MANJŠALNICE V PRLEŠKIH NAREČNIH SLOVARJIH}

\section{CoBISS: 1.01}

\begin{abstract}
Prispevek zarisuje obseg samostalniških manjšalnic, tj. modifikacijskih izpeljank, $v$ treh prleških narečnih slovarjih: v slovarju Gúčati po antùjoško (Bernard Rajh, 2010), Cerkvenjaškem besednjaku - Antujoškem besednjaku (Ciril Paluc, 2010) in Slovarju severovzhodnega ormoškega govora s kratkim opisom (Ciril Vnuk, 2012). Primerjalno jih obravnava $\mathrm{z}$ vidika rodnosti in razvrstitvenih lastnosti obrazil.

Ključne besede: besedotvorje, manjšalnice, panonska narečna skupina, prleško narečje, prleški narečni slovarji
\end{abstract}

\section{Nominal Diminutives in Prlekija Dialect Dictionaries}

This article focuses on the corpus of nominal diminutives (i.e., modification word-formations) in three Prlekija dialect dictionaries: Gúčati po antùjoško (Bernard Rajh, 2010), Cerkvenjaški besednjak-Antujoški besednjak (Ciril Paluc, 2010), and Slovar severovzhodnega ormoškega govora s kratkim opisom (Ciril Vnuk, 2012). It compares them based on productivity and the classification characteristics of word-formation affixes.

Keywords: word formation, diminutives, Pannonian dialect group, Prlekija dialect, Prlekija dialect dictionaries

\section{UVOD}

Po Ireni Stramljič Breznik (2008: 56) manjšalnice, tj. samostalniške tvorjenke, ki se uvrščajo med modifikacijske izpeljanke (Toporišič 1992: 100; 2000: 183187), s pomenskega vidika izražajo manjšo mero podstave in načeloma objektivno poimenujejo pojavnost glede na velikost druge take pojavnosti. V slovenščini se manjšalnost uporablja tudi za izražanje stopnjevitosti ali čustvenosti (ljubkovalno-manjšalno, slabšalno-manjšalno), manjšalna obrazila pa so pogosta tudi pri poimenovanju mladičev oz. nedoraslosti (Stramljič Breznik 2008: 56). Rajna Dragićević (2015) ugotavlja, da ima večina samostalniških manjšalnic samo en, tj. manjšalni pomen, hkrati pa opozarja, da nekatere izmed njih ob manjšalnem razvijejo tudi nemanjšalni pomen, in sicer (kontinuirano) od blage zaznamovanosti osnovnega manjšalnega pomena (npr. ljubkovalnost, slabšalnost, evfemističnost) preko osamosvojenega pomena znotraj večpomenske strukture manjšalnice1 do

Prispevek je bil predstavljen na 3. Slovenskem dialektološkem posvetu (SDP 3), ki sta ga 11. in 12. februarja 2016 v Ljubljani organizirala Inštitut za slovenski jezik Frana Ramovša ZRC SAZU in Oddelek za slovenistiko Filozofske fakultete Univerze v Ljubljani.

1 Rajna Dragićević (2015) pripisuje manjšalnicam možnost razvoja polisemije, pri čemer se sekundarni pomen manjšalnic najpogosteje razvije zaradi metaforičnega ali metonimičnega prenosa. 
popolne osamosvojitve pomena oz. leksikalizacije. Novi leksem ima nemanjšalni, samosvoj pomen, osamosvojen od prvotnega manjšalnega pomena.

\section{PRIKAZ TVORBENIH OBRAZIL MANJŠALNIC V PRLEŠKIH NAREČNIH SLOVARJIH}

Prispevek zarisuje obseg samostalniških manjšalnic, obravnavanih z vidika rodnosti in razvrstitvenih lastnosti obrazil, v treh prleških narečnih slovarjih. Osnova za obravnavo so izpisi iz narečnega slovarja Gúčati po antùjoško Bernarda Rajha (2010),2 Cerkvenjaškega besednjaka - Antujoškega besedjaka Cirila Paluca (2010) in Slovarja severovzhodnega ormoškega govora s kratkim opisom Cirila Vnuka (2012). Rajhov slovar obsega okrog 10.000, Palučev okrog 9000, Vnukov pa okrog 3700 besed. Največ samostalniških manjšalnic prinaša Rajhov slovar, najmanj Vnukov. V Gúčati po antùjoško (GPA) imajo manjšalnice 2,4-odstotni delež, v Cerkvenjaškem besednjaku (CB) znaša ta 1,41 \%, v Slovarju severovzhodnega ormoškega govora (SSOG) pa 2,65 \%. Različna je tudi razporeditev manjšalnic po spolih. V cerkvenjaškem govoru prevladujejo ženskospolske manjšalnice, v ormoškem govoru pa je število moškospolskih manjšalnic za tretjino večje od števila ženskospolskih manjšalnic. 3 Srednjespolskih tvorjenk je malo, še največ jih izpričuje Rajhov slovar.

\section{Preglednica 1: Primerjava obsega manjšalnic v prleških slovarjih}

\begin{tabular}{|c|c|c|c|c|c|c|}
\hline & GPA & $\%$ & CB & $\%$ & SSOG & $\%$ \\
\hline $\begin{array}{l}\text { Moškospolske } \\
\text { manjšalnice }\end{array}$ & 111 & 46,25 & 60 & 47,25 & 56 & 57,14 \\
\hline $\begin{array}{l}\text { Ženskospolske } \\
\text { mnajšalnice }\end{array}$ & 121 & 50,42 & 63 & 49,60 & 38 & 38,77 \\
\hline $\begin{array}{l}\text { Srednjespolske } \\
\text { manjšalnice }\end{array}$ & 8 & 3,33 & 4 & 3,15 & 4 & 4,1 \\
\hline$\underline{\text { Skupaj }}$ & 240 & 2,4 & 127 & 1,41 & 98 & 2,65 \\
\hline
\end{tabular}

\subsection{Manjšalnice v narečnem slovarju Gúučati po antùjoško (Rajh 2010)}

Pregled tvorbenih obrazil manjšalnic, izpričanih v Gúčati po antùjoško, kaže, da manjšalnice moškega in ženskega spola izkazujejo enako tvorbeno raznolikost, medtem ko so manjšalnice srednjega spola tovrstno manj raznolike.

\subsubsection{Manjšalnice moškega spola}

Obrazila manjšalnic moškega spola si glede na tvorbeno rodnost padajoče sledijo v naslednjem zaporedju: -ek (glažek), -ec (bikec), -ček (čebrček), -ič (tramič), -c

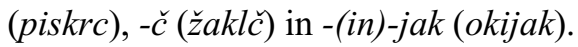

2 Rajh svoje delo v podnaslovu poimenuje Gradivo za narečni slovar severozahodnoprleškega govora.

3 Moškospolske manjšalnice so številčnejše tudi v prekmurskem narečju. V beltinskem govoru jih je za polovico več kot ženskospolskih, v porabskih govorih pa je razlika med njimi več kot $10 \%$ (Koletnik 2015: 451). 
Najrodnejše je obrazilo -ek s 54 tvorjenkami. Najpogosteje se dodaja glasovno nepremenjeni podstavi: atek, camblek 'kembeljček', črvek, dedek, glažek, golobek, grozdek, hujdiček, kladek, klüček, knofek, kolaček, košek, kozlek, kujek, lampek, lasek, listek, loparek, maclek 'kladivce', mujcek, nožek, pebarek 'fantič(ek)', pehek 'kijec, batek', pesek 'psiček', pilek (< pildek), pišek, plohek, potaček, prstek, püčelek, püšlek, rilek 'hlodek', stolek, talerek, telek, tramek, vozek, zizek 'manjši sesek', manj pogosto na palatalizacijsko premenjeni podstavi na -c: iček 'teliček', jünček, kunček, polček (<polc 'opornik'), puček 'pujsek', robček, ali na $-k$ : srmaček, štriček. Iz slovarja je razvidna tudi tvorba manjšalnic na -ek kot drugostopenjskih tvorjenk iz tvorjenih podstav na -ec (ajngelček, falaček, klinček, zvunček) in -c (haklček). Mujcek in telek imata v slovarju pripisan dodatni kvalifikator ekspresivno, camblek, stolek, talerek, tramek in zvunček pa imajo narečno uveljavljene sopomenke camblček, stolec, talerček in talarček, tramič in zvunec. Kot manjšalnici bi bilo mogoče obravnavati tudi tvorjenki drobižek 'droben otrok' in cartek 'razvajenček, ljubljenček'. Drobižek izraža sočutje ali usmiljenje do osebe, poimenovane $\mathrm{z}$ manjšalnico, $\mathrm{v}$ primeru cartek pa je moškospolsko obrazilo -ek dodano ženskospolski podstavi (carta 'razvajenec, ljubljenec').

Primerov česnik 'česen', cincek 'malo ali nedoraslo bitje' in fiček 'fičko' ne opredeljujemo kot manjšalnice, saj pripona tvorjenk besednopomensko ne opredeljuje, ampak ima le strukturalno funkcijo. Tudi leksemi ječmenček (s sopomenko ječmenec) 'gnojno vnetje obočesne lojnice', sirek 'vrsta okrasnega grma, sneženka', soldaček 'majhna ciklama' (< soldak 'ciklama'), trsek 'okrasna cvetica' in jarmek 'stranski klin pri jarmu, jarmnik', katerih sekundarni pomen se je razvil zaradi metaforičnega prenosa na osnovi videza (podobnost), oblike ali metonimije, funkcionirajo kot tvorjenke le na strukturni ravni in $\mathrm{z}$ vidika besedotvornega pomena niso manjšalnice. Izglagolska tvorjenka cecek (< cecati 'sesati', kar je splošnoslovanska onomatopeja iz otroškega jezika - ESSJ 1: 59) ni manjšalnica, čeprav bi manjšalni pomen lahko motivirala ločitev dela od celote (Merše 2010: 48). Med navidezne manjšalnice uvrščamo še izglagolsko tvorjenko brodek (s sopomenko brodec) 'slinček’ in samostalnik jürek, ki se v slovarju pojavlja vzporedno ob samostalniku jüri 'tisočak', to pa ga opredeljuje kot sopomenko, zato mu ni mogoče pripisati manjšalnostnega pomena. Tudi lorbek in pusek se le navidezno pridružujeta manjšalnicam, saj gre za fonološko oz. morfološko prilagojeni različici nemških poimenovanj Lorbeer 'lovor' in Kuss 'poljub'. V primerih kosek 'kos (ptica)' in prašiček 'prašič' je v narečju prišlo do popolne osamosvojitve pomena oz. leksikalizacije.

Drugo najpogostejše obrazilo je -ec s tvorjenkami brez premen, npr. akec 'drekec', bakec 'teliček', bikec, Bogec, cepec, cvekec, čikec 'teliček', drekec, grahec, irgec 'tepček', jarkec, klinec 'klinček', korpec, križec, lükec, plehec, puhec 'prašiček', roglec, stolec, šekec 'lisasti bikič', škafec, štilec, zobec 'zobček', zvu$n e c$, ali s premeno zaradi podstave na $-k$ : rinčec. Manjšalnicam akec, Bogec in čikec je v slovarju pripisan kvalifikator ekspresivno. Bikec, stolec in zvunec imajo sopomenske dvojnice bikič, stolek in zvunček. 
Med navidezne manjšalnice uvrščamo leksem publec, ki ima v narečju uveljavljeno sopomenko puba 'fant', saj pri publecu ni mogoče odkriti sobesedilnih znakov za manjšalni pomen. Kot manjšalnico je tako mogoče leksem opredeljevati le na strukturni, ne pa na semantični ravni. Pomenotvornega in ne besedotvornega nastanka so še leksemi drobec 'drobir; ostanek na rešetu pri mlačvi', kjer bi manjšalni pomen lahko motivirala ločitev dela od celote, jugec, ki poimenuje tip manjšega osebnega avtomobila znamke Crvena zastava jugo, ter samostalniki ječmenec (s sopomenko ječmenček), ogjec 'ognjič', lipek 'naivnež, neroda' in marulek 'revše', katerih sekundarni pomen se je razvil zaradi metaforičnega prenosa na osnovi videza oz. kolektivne ekspresije. Izglagolska tvorjenka prdec $(<$ prdeti) ni manjšalnica, čeprav bi manjšalni pomen lahko motivirala kratkotrajnost dejanja, kar pa ni v skla$\mathrm{du}$ z besedotvorno teorijo, po kateri so manjšalnice le izsamostalniške tvorjenke.

Po pogostnosti pojavljanja sledi obrazilo -ček $k^{4} 16$ tvorjenkami: bobenček, camblček 'kembeljček', čebrček, falarček '(zidani) stebriček', haklček, hamrček, kamček,5 ladlček, mašlček, penzlček, špeglček, štiklček, štinglček, talarček in telerček 'oboje manjši krožnik' ter žaklček. Pleteršnikov slovar nima nobene izmed navedenih tvorjenk, SSKJ pa beleži manjšalnici bobenček in žakeljček, in sicer kot tvorjenki z že posplošenim obrazilom -ček. Camblček ima sopomensko dvojnico camblek, talarček in talerček pa imata sopomenko talerek.

Obrazilo -ič, ki je z izjemo manjšalnice vršič nenaglašeno, izkazuje sedem primerov: bikič, grüntič, kokotič, krampič, rožič 'del tulca govejega roga, ki se uporablja pri polnjenju klobas', tramič in vršič 'vrh rastline'. Največkrat se dodaja glasovno nepremenjeni podstavi, redkeje palatalizacijsko premenjeni podstavi na -g (rožič) oz. -h (vršič). Bikič ima narečno uveljavljeno sopomenko bikec, tramič pa tramek. Vršič kaže metaforično asociacijo na osnovi oblike in položaja.

Tvorjenki lümpič in kümič (s sopomenko kün) sta navidezni manjšalnici, saj gre za morfološko prilagojeni izposojenki iz bav. avstr. Lumpe 'ledvica' in kümm 'kumina' (DLS: 173; ESSJ 2: 110).

Manj rodni sta obrazili $-c$ in $-\check{c}$. Obrazilo $-c$ je izpričano pri tvorjenkah aškrc6 'košček', haklc 'kaveljček', piskrc, püšlc in štinglc 'peceljček', obrazilo - $\check{c}$, ki je reducirana različica obrazila -ič, pa se razvršča za zvočnikom - $l$, na katerega se končuje podstava: reglč 'manjši hlod/kos lesa', žaklč 'manjša vreča' in hublč 'oblič', ki izkazuje majhnost v primerjavi z izhodiščnim samostalnikom hobl '(večji) oblič'.

Z enkratno pojavitvijo je v slovarju zastopano še obrazilo -(in)-jak. Slovarska razlaga, pripisana samostalniku okijak (<okn-in-jak) 'manjše okno brez zasteklitve (npr. v kleti)', sicer kaže na njegov manjšalni pomen, njegova strukturna podoba pa ne.

Irena Stramljič Breznik (2008: 60) piše, da moškospolske manjšalnice z obrazilom -ček načeloma nastajajo takrat, ko je izglasje podstave zvočnik. Ločujemo jih od tvorjenk z izglasjem na -ček, pri katerih gre samo za glasovno premenjeno obliko.

$5 \quad$ V primeru kamček (< kamenček) je opaziti izpad zloga.

6 Po Pleteršniku je oblika $a s ̌ k r c ~ » m e n d a$ nam.[esto] aškrtec, dem.[inutiv] aškrt«. 


\subsubsection{Manjšalnice ženskega spola}

Pri tvorbi manjšalnic ženskega spola so izpričana obrazila -ica (mravlica), -ca (metlca), -ika (rožika), -ka (kočka) in -(in)-ka (štalinka).

Najrodnejše ženskospolsko obrazilo je -ica, ki je kdaj tudi naglašeno (gorica, košìca, mejìca, stolìca, vedrica). Dodaja se glasovno nepremenjeni podstavi: amica, babica, gorica, gumica, grüdica, hojkica, jarkica 'mlada kokoš' $(<$ jarka), jenkica, jivica, kantica, kartica, klanfica, klingica, klobkica, kokica, krožica (< kroža 'večji kozarec'), kupica, kurvica, lampica, laptica 'latica', lestvica, markica 'znamkica', motkica, mravlica, okica 'očesce', pikica, pilkica, rantica, regica 'manjša zelena žaba' (< rega 'žaba'), ročkica 'manjši vrč', sklojzica, stolica 'manjša klop', šajbica, štengica 'drogec', vedrica, žagica, ali palatalizacijsko premenjeni podstavi, če se ta končuje na $-k$ : rinčica. Iz slovarja je razvidna tudi tvorba manjšalnice na -ica kot drugostopenjske tvorjenke iz tvorjene podstave na -ka: krtačkica $(<k r t a c ̌ k a)$. Jotacijsko premenjena je tvorjenka košica. Manjšalnici kokica in kurvica imata pripisan dodatni kvalifikator ekspresivno. $\mathrm{V}$ primeru vedrica je ženskospolsko obrazilo -ica, s katerim navadno izpeljujemo manjšalnice iz ženskospolskih samostalnikov, dodano srednjespolski podstavi. Manjšalnica okica ima sopomensko dvojnico okika.

Skupino razširjajo leksemi, katerih sekundarni pomen se je razvil zaradi metaforičnega prenosa na osnovi videza (podobnosti), oblike, razširitve prvotnega pomena ali kolektivne ekspresije: iglica 'vlečni klin pri ojesu', kopica 'stog', ribica 'ledvica', müšica 'mušica, tj. majhni muhi podobna žuželka' (<muh-ica), šibica 'vžigalica', žabica 'obešanka', knižica 'izkaznica (dokument)', mejica 'porasel svet ob meji', ročica 'navpična opornica pri vozu' $(<$ rok-ica). Ti kot tvorjenke funkcionirajo le na strukturni ravni. V primeru tetica 'teta' je prišlo do osamosvojitve pomena oz. leksikalizacije.

Drugo najpogostejše je obrazilo - $c a$, ki je lahko tudi reducirana različica obrazila -ica (npr. sekirca < sekirica): blajca, deklinca, garca 'manjša lojtrnica za voz', gožca 'manjša vrbova šiba', grabca 'del vinograda', grolca, iglca, iskrca, jedrca 'jedrce', kahlca 'ploščica', kanglca, kaplca, ketnca, kobilca '(zelena) kobilica', krüglca, lüknca, merca, metlca, mlinca 'manjši mlin', mrkevca, omarca, renglca, sekirca, süknca, šaflca, šauflca 'lopatka', šifrca 'košček', škatlca, štalca '(v hlevu) ograjen prostor za svinjo', tablca in žnürca. Šaflca in šauflca sta sopomenski dvojnici. Blajca je narečno uveljavljena sopomenka blajčike, deklinca pa deklinčike. V primeru jedrca je ženskospolsko obrazilo - $c a$ dodano srednjespolski, v primeru mlinca pa moškospolski podstavi. Pri štalci z narečno sopomenko štalinka manjšalni pomen motivira izražena majhnost oz. delnost v primerjavi s celoto. Skupino razširjajo še množinski samostalniki jaslce, orglce in vilce, izpeljani iz istospolnih nemanjšalnih množinskih samostalnikov, kjer se obrazilo -ice realizira kot -ce (npr. jasli $\rightarrow$ jaslice $\rightarrow$ jaslce).

Samostalniki detelca, sparca in štegnca, narečno uveljavljene sopomenke leksemov detela 'detelja', sparina 'sopara, vročina' in štega 'stopnica', se uvrščajo med navidezne manjšalnice, saj knjižna slovarska ustreznica ne izkazuje 
manjšalnostnega pomena. Leksema postelca 'posteljica (pri kravi)' in kapca 'sprednji del/konica čevlja/prsta', katerih sekundarni pomen se je razvil zaradi metaforičnega prenosa na osnovi funkcije ali razširitve prvotnega pomena, sta pomenotvornega in ne besedotvornega nastanka. $\mathrm{V}$ primeru greblca '(lesena) grebljica (za peč)' je prišlo do osamosvojitve pomena oz. leksikalizacije.

Po pogostnosti pojavljanja sledi obrazilo -ika. Dodaja se glasovno nepremenjeni podstavi, npr. botrika, cartika 'razvajenček' (< carta 'razvajenec, ljubljenec'), cejika, cüzika 'telička', čelika 'čebelica', drevika, kozika, krastika, kravika, mamika, mujcika, okika 'očesce', perika 'peresce', pupika, rečika 'stvarca', rožika, sestrika, sklojzika, žüžika 'živalica', ali palatalizacijsko premenjeni podstavi, če se ta končuje na - $c$ : dečika 'otročič(ek)', ičika 'živinica, živinče' $(<i c a)$, jajčika, majčika 'majička', ovčika, rečika 'račka', šalčika. Iz slovarja je razvidna tudi tvorba manjšalnic na -ika kot drugostopenjskih tvorjenk iz tvorjene podstave na -ca: blajčika 'deščica' (< blajca), deklinčika 'dekletce'(< deklinca). Okika ima sopomensko dvojnico okica, cejika je dvojnica cenki, blajčika sobiva z blajco in deklinčika z deklinco. Skupino razširjajo še cincika 'malo/nedoraslo žensko bitje', ki ima v slovarju pripisan kvalifikator ekspresivno, bumbika 'popek, poganjek' in popika 'brst, poganjek', ki jih je mogoče kot manjšalnice obravnavati le na strukturni ravni.

Obrazilo - $k a$ tvori 20 primerov. Dodaja se glasovno nepremenjeni podstavi, npr. blazinka, cenka 'košarica z enim ročajem', črpajka 'skledica posodica', hiška 'mala soba', kobačka 'kletkica', kočka, kopajka 'manjše korito', krpačka 'manjša slamnata (skledasta) posoda', lüčka, sejačka 'manjša slamnata posoda', sla(m)jačka 'manjša košara iz slame', tünka 'manjša deža/posoda za mast', ali palatalizacijsko premenjeni podstavi na -c: košička, krnička 'lesena posodica', osmička, sedmička, telička. Iz slovarja je razvidna tudi tvorba manjšalnic na $-k a$ kot drugostopenjskih tvorjenk iz tvorjene podstave na -ica: kadička, pešička, sklečka. Manjšalnica cenka ima sopomensko dvojnico cejika.

Leksem ficka 'mala količina, malenkost' manjšalnega pomena ne pridobiva primerjalno s podstavnim samostalnikom, ampak v primerjavi s celoto, zato ga je treba opredeljevati kot pomenotvorno in ne besedotvorno nastalo besedo.

Manj rodno (z enkratno pojavitvijo) je v narečju obrazilo -(in)-ka (štalinka '(v hlevu) ograjen prostor za svinjo'), kjer manjšalni pomen motivira izražena majhnost oz. delnost v primerjavi s celoto. Štalinka je narečno uveljavljena sopomenka besede štalca.

Gradivo izkazuje še besedo babina 'ženička', ki pa je manjšalna le na semantični, ne pa tudi na besedotvorni ravni. Pripona -ina tvorjenke ne modificira $v$ smeri manjšalnosti.

\subsubsection{Manjšalnice srednjega spola}

$\mathrm{V}$ cerkvenjaškem govoru nastajajo srednjespolske manjšalnice $\mathrm{z}$ obrazili -e (piše 'pišče', prase 'mlad prašič', siroče, srmače, žrebe), -(č)e (živinče 'mlado govedo'), 
-ce (kolce 'kolešček') in -ca (dverca 'vratca'). V primeru dverca se srednjespolsko obrazilo - $c a$ druži z ženskospolskim množinskim samostalnikom dveri.

\subsection{Manjšalnice v Cerkvenjaškem besednjaku - Antujoškem besednjaku (Paluc 2010)}

Pregled tvorbenih obrazil manjšalnic v CB (besede v njem niso onaglašene) pokaže, da v tem slovarju največjo tvorbeno raznolikost izkazujejo manjšalnice moškega spola, manj tvorbeno raznolike so manjšalnice ženskega spola, najmanj pa manjšalnice srednjega spola.

\subsubsection{Manjǔsalnice moškega spola}

Obrazila manjšalnic moškega spola si glede na tvorbeno rodnost padajoče sledijo v naslednjem zaporedju: -ek (klüček), -ec (korpec), -ič (bikič), -c (žaklc) in enako pogosto - $\check{c}$ (hoblč), -ic (pejic < pahic) in -(in)-jak (okijak).

Najrodnejše moškospolsko obrazilo v CB je -ek s sedemindvajsetimi tvorjenkami. Najpogosteje se dodaja glasovno nepremenjeni podstavi (batek, čepek, dedek, hujdiček, kladek, klüček, kolaček, košek, lampek, nožek, maclek, ${ }^{7}$ mujcek, pesek, pišek, pičelek ali püčelek 'sodček', pilek ali pildek 'kartonček z nabožno podobo', špe$h e k$, vozek), manj pogosto pa palatalizacijsko premenjeni podstavi na $-k$ (človeček) ali -c (žrebček). Iz slovarja je razvidna tudi tvorba manjšalnic na -ek kot drugostopenjskih tvorjenk iz tvorjenih podstav na -ec (falaček, kamenček, $\mathbf{8}$ klinček, ropčeki) in -ič (čebriček). Manjšalnici dedek in mujcek imata v slovarju dodatni kvalifikator ljubkovalno, čebriček pa ima narečno uveljavljeno sopomenko čebrič.

Pomenotvornega in ne besedotvornega nastanka so leksemi čolniček 'del stroja za šivanje', ječmenček (s sopomenko ječmenec) 'vnetje lojnic v očesnih vekah', trsek 'vrsta vzpenjajoče se cvetne rastline', lipek 'človek mehkega značaja, nerodnež' in jarmek 'železna igla, ki jo vstavijo na zunanji strani jarma', katerih sekundarni pomen se je razvil zaradi metaforičnega prenosa (na osnovi videza, oblike ali kolektivne ekspresije) ali metonimije. Kot pomenotvorno in ne besedotvorno nastali besedi je treba opredeljevati tudi leksema balažek 'majhen želarski voz' in ficek 'malenkost, izredno malo v količini ali vrednosti', ki manjšalnega pomena ne pridobivata primerjalno s podstavnim samostalnikom.

Izglagolske tvorjenke cecek 'sesek', odtisek, scedek, zavrtek, zgrizek in zizek 'sesek' niso manjšalnice, čeprav bi pri nekaterih od njih manjšalni pomen lahko motivirala ločitev dela od celote ali kratkotrajnost dejanja (prim. Merše 2010: 48), kar pa ni v skladu z besedotvorno teorijo. Med navidezne manjšalnice uvrščamo tudi samostalnike dodlek, jürek in lajbek. V slovarju se pojavljajo vzporedno ob samostalnikih dodl 'neumnež', jüri 'tisočak' in lajb 'oprsnik', kar jih opredeljuje

7 To je predpostavljena edninska oblika, saj slovar beleži samo množinsko obliko macleki 'lesena kladivca ali tolkači vinogradniškega klopotca'.

8 Pleteršnik tvorjenko razlaga kot manjšalnico k podstavi z izglasjem na -ec (kamenčək-čka, dem. kamenec), SSKJ pa kot tvorjenko z že posplošenim obrazilom -ček. 
kot sopomenke, zato jim ni mogoče pripisati manjšalnostnega pomena. Tudi lorbek, pusek in šnitlek se le navidezno pridružujejo manjšalnicam, saj gre za fonološko oz. morfološko prilagojene različice nemških poimenovanj Lorbeer 'lovor', Kuss 'poljub' in Schnittlauch 'drobnjak'. Pripone imajo strukturalni, na pa tudi besedotvorni pomen. Le na strukturni ravni tvorjeni sta še besedi česnek 'česen' in prašiček 'svinjski samec (običajno že kastriran ali skopljen)'; z vidika besedotvornega pomena nista manjšalnici.

Drugo najpogostejše obrazilo je -ec s tvorjenkami brez premen (bogec, cepec, čikec 'teliček', drekec, grahec, holmec 'manjši breg', klinec, korpec, lükec, plehec, robec, stolec, špehec, špukec 'manjši pljunek', životec) ali s premeno zaradi podstave na $-k$ (rinčec). Manjšalnica cepec ima sopomenko cepič, manjšalnici životec pa je v slovarju pripisan kvalifikator ljubkovalno.

Skupino razširjajo še drobec 'drobir; ostanek na rešetu pri mlačvi', kjer bi manjšalni pomen lahko motivirala ločitev dela od celote, ter ječmenec (s sopomenko ječmenček), ogjec (s sopomenko ognič) 'ognjič' in puhec 'pujsek', katerih sekundarni pomen se je razvil zaradi metaforičnega prenosa. Te besede so pomenotvornega in ne besedotvornega nastanka. Med navidezne manjšalnice se uvrščata samostalnik vukec, narečno uveljavljena sopomenka leksema vuk 'plod hrasta (»Šiška«)', katere knjižna slovarska ustreznica ne izkazuje manjšalnostnega pomena, ${ }^{9}$ in izglagolska tvorjenka brodec 'slinček'. Izglagolske tvorjenke tipa füčkec, pezdec 'tihi prdec', prdec (< prdeti) niso manjšalnice, čeprav bi manjšalni pomen lahko motivirala kratkotrajnost dejanja, kar pa ni v skladu z besedotvorno teorijo, po kateri so manjšalnice le izsamostalniške tvorjenke.

Po pogostnosti pojavljanja sledi obrazilo -ič z osmimi tvorjenkami. Dodaja se glasovno nepremenjeni podstavi: bikič, brstič 'rastni nastavek, poganjek', cepič 'cepec', čebrič, lagvič, žaklič, ali palatalizacijsko premenjeni podstavi na -g: rožič 'roževinast lijak (odrezan del kravjega roga)', ali - $h$ : vršič 'štrleči vrh drevesa'. Manjšalnice cepič, čebrič in žaklič imajo sopomenske dvojnice cepec, čebriček in žaklc. Rožič ustvarja predstavo majhnosti v primerjavi s celoto oz. okoliščinami rabe, z brstičem pa je izražena mlada rastlina, ki zaradi svoje mladosti še ni dosegla končne velikosti (prim. Merše 2010: 56).

Beseda lumpič je navidezna manjšalnica, saj gre za morfološko prilagojeno različico bav. avstr. Lumpe 'ledvica' (DLS: 173), kjer ima pripona strukturalni, ne pa tudi besedotvorni pomen. Pomenotvornega in ne besedotvornega nastanka je leksem ognič (s sopomenko ogjec) 'ognjič'.

Nekoliko manj rodno je obrazilo - $c$ s šestimi primeri: aškrc z različico aškerc 'košček, ščip, odlomek', ceglc z različico cetlc 'listek', püšlc ‘šopek', kar je predpostavljena edninska oblika v slovarju navedene množinske oblike püšlci 'različni šopki svatov, koscev, žanjic, nabornikov', ter žaklc (s sopomenko žaklič).

9 Navedena je predpostavljena edninska oblika, saj slovar beleži samo sopomensko množinsko obliko vukeci ali vuki 'plodovi hrasta (»šiške«)'. 
$\mathrm{Z}$ enkratno pojavitvijo so $\mathrm{v}$ slovarju izpričana še obrazila $-\check{c}$, -ic in -(in)-jak. Obrazilo - $\breve{c}$, ki je reducirana različica obrazila -ič, se razvršča za zvočnikom -l, na katerega se končuje podstava: hoblč 'manjši ročni skobeljnik'. Obrazilo -ic izkazuje primer pejic (< pahic) 'kratki tram, tramič', ki je predpostavljena edninska oblika v slovarju navedene množinske oblike pejici. Manjšalni pomen 'kletna lina, majhno kletno okno; majhno okence v zimskem okenskem okvirju' je v slovarju pripisan samostalniku okijak $(<o k n$-in-jak).

\subsubsection{Manjǔalnice ženskega spola}

Pri tvorbi manjšalnic ženskega spola so izpričana obrazila -ica (žagica), -ca (kanglca), -ka (flaška), -ika (mamika), -ačka in -arka/-orka (cejačka, cejarkal cejorka), slednji z enkratno pojavitvijo.

Najrodnejše je obrazilo -ica. Dodaja se glasovno nepremenjeni podstavi (amica, babica, gorica, gümpica 'drobna grudica', hamica, jarkica 'mlada kokoš', jenkica, klingica, klüpica 'ščipalka', krožica 'kupica' (< kroža 'velik kozarec'), kupica, lampica, lestvica, markica, mejica, murkica 'majhna kumarica', pogačica 'majhna pogača', redkvica, ribica 'majhna riba', šajbica, žabica 'majhna žaba', žagica) ali palatalizacijsko premenjeni podstavi, če se ta končuje na -k (rinčica). ${ }^{10}$ Tvorjenki klüpica in krožica imata narečno uveljavljeni sopomenski dvojnici klüpca in krožca. Skupino razširjajo še množinska samostalnika bükvice in orglice, izpeljana iz istospolnega nemanjšalnega množinskega samostalnika $\mathrm{z}$ obrazilom -ice (bukve, orgle $\rightarrow$ bukvice, orglice), ter samostalnik vedrica $\mathrm{z}$ glasoslovno različico vidrica in srednjespolski podstavi dodanim ženskospolskim obrazilom. Jotacijsko premenjeni sta podstavi tvorjenk košica 'odlomek kosti; peška' in pešica 'peščica'. V primeru tetica 'teta' je prišlo do osamosvojitve pomena oz. leksikalizacije.

Pomenotvorno nastale besede so kopica 'kopica slame ali sena na prostem,' mišica 'majhni muhi podobna žuželka' (<muh-ica), štengica 'listič žvepla' (< śtangica 'drogec'), ribica 'ledvica', žabica 'obešanka', ročica 'pokončno stoječa ročica pri kmečkem vozu' (< rok-ica), rokica 'poševni veznik (podporna roka) v lesenem ostrešju'.11

Po pogostnosti pojavljanja sledi obrazilo - $c a$, reducirana različica obrazila -ica: blazinca, detelca 'mlada detelja', gorca 'del vinograda', gožca, grolca 'jagodica ali kroglica (v pomanjševalnem pomenu)', kahlca 'keramična ploščica', kanglca, kaplca, ketnca, klüpca, krožca, kuglca, merca, postelca 'majhna ali otroška postelja', renglca ali rajnglca 'zelo mala ponev', šaflca, škopca, štalca

10 Tvorjenke gümpica, murkica, pogačica in ribica so predpostavljene edninske oblike v slovarju izpričanih množinskih oblik gümpice 'drobne grudice', murkice 'majhne kumarice', pogačice 'majhne pogače' in ribice 'majhne ribe'.

11 Tvorjenka rokica je predpostavljena edninska oblika v slovarju izpričane množinske oblike rokice 'poševni vezniki (podporne roke) v lesenem ostrešju'. 
'svinjak za eno žival', žnürca.12 V primeru gorca in štalca manjšalni pomen motivira izražena majhnost oz. delnost v primerjavi s celoto. Manjšalnici klüpca in krožca imata sopomenski dvojnici klüpica in krožica.

Med navidezne manjšalnice uvrščamo samostalnika štegnce in klüpca, narečno uveljavljeni sopomenki leksemov štenge 'stopnice' in klüpa 'kljuka na vratih', katerih knjižni slovarski ustreznici ne izkazujeta manjšalnostnega pomena. Pomenotvorno nastale besede so garce $\mathbf{1 3}$ 'stranice manjših vozov, podobne položenim lestvam', malinca 'murva', postelca 'porodna posteljica', kobilca 'žuželka';14 njihov sekundarni pomen se je razvil zaradi metaforičnega prenosa na osnovi videza, oblike, funkcije ali kolektivne ekspresije. V primeru greblca 'orodje za poravnavanje žerjavice v krušni peči in spravljanje pepela iz peči’ je prišlo do leksikalizacije.

Po pogostnosti pojavljanja sledita obrazili $-k a$ in $-i k a$. Obrazilo $-k a$ se dodaja glasovno nepremenjeni podstavi (flaška, hiška, kočka, ritka, žlička) ali palatalizacijsko premenjeni podstavi na -c (krnička), iz slovarja pa je razvidna tudi tvorba manjšalnic na $-k a$ kot drugostopenjskih tvorjenk iz tvorjene podstave na -ica (sklečka); obrazilo -ika se dodaja glasovno nepremenjeni podstavi (mamika, s pripisanim kvalifikatorjem ljubkovalno), mujcika15 ali palatalizacijsko premenjeni podstavi, če se ta končuje na -c (ičika $(<i c a)$ 'telička, kravica', ofčika in šalčika).

Skupino razširja še leksem cincika 'samica iz vrste majhnih kokoši; ženska manjše rasti', ki pa ga je mogoče kot manjšalnico obravnavati le na strukturni ravni.

Manj rodni, izpričani z enkratno pojavitvijo, sta obrazili -ačka (cejačka) in -arka/-orka (cejarka z glasoslovno različico cejorka 'majhna košarica iz šibja pintovca').

\subsubsection{Manjšalnice srednjega spola}

Srednjespolske manjšalnice največkrat nastajajo z obrazilom -e: prase 'pujsek', sroče $\mathrm{z}$ različico siroče, redkeje $\mathrm{z}$ obrazilom -(̌̌)e: živinče.

\subsection{Manjšalnice v Slovarju severovzhodnega ormoškega govora s kratkim} opisom (Vnuk 2012)

V Slovarju severovzhodnega ormoškega govora s kratkim opisom manjšalnice moškega in ženskega spola izkazujejo enako tvorbeno raznolikost, medtem ko so manjšalnice srednjega spola tovrstno manj raznolike.

12 Tvorjenki kahlca in kaplca sta predpostavljeni edninski obliki v slovarju izpričanih množinskih oblik kahlce 'keramične ploščice' in kaplce 'kapljice'.

13 V primeru tega množinskega samostalnika je ženskospolsko manjšalno obrazilo -ca realizirano kot $-c e$.

14 Tvorjenki gomilca in kobilca sta predpostavljeni edninski obliki v slovarju izpričanih množinskih oblik gomilce 'kamilice' in kobilce 'vrsta žuželk'. Predpostavljena edninska oblika v slovarju zabeležene množinske oblike mujcike 'mačji mladiči’. 


\subsubsection{Manjšalnice moškega spola}

Obrazila manjšalnic moškega spola si glede na tvorbeno rodnost padajoče sledijo v naslednjem zaporedju: -ek (kolaček), -ec (korpec), -ič (lagvič), -c (püšlc) in $-(i) \check{c}(h o b l(i) \check{c})$.

Najrodnejše manjšalno moškospolsko obrazilo je -ek z 39 tvorjenkami. Najpogosteje se dodaja glasovno nepremenjeni podstavi (båbek, bajdlek 'manjša globoka pločevinasta skleda', bambrlek 'manjši cof', cicek 'majhen sesek ali dojka', čehek, črvek, dodlek 'tepček', glažek, gudek 'mlad prašič', ke(i)nžlek 'kamenček', klüček, kolaček, kotaček 'kolesce', kozek 'kozlič, kozji mladič', krühek, maclek, medek 'medvedek', ormarek, pajbek 'fantek, deček', pajcek 'pujsek', petlek 'posteljica', picek, purek 'purji mladič', reček 'raček', šprudlek, vajdlek, zavek 'zajčji mladič', zizek), manj pogosto pa palatalizacijsko premenjeni podstavi na -c (lanček 'verižica', lunček, patrček 'majhen kos lesa', (s)krajček, vüjček, zdenček 'studenček', zvunček) ali - $k$ (srmaček). Z obrazilom -ek nastajajo tudi drugostopenjske tvorjenke; -ek se pritika ali na obrazilo -ec (brešček 'manjšalnica od breg, bregec', fålaček) ali na obrazilo -ič (korpiček). Kazalka z okrajšavo gl. pri iztočnici vajdlek kaže na narečno uveljavljeno sopomenko bajdlek, pri iztočnici zizek pa na sopomenko cicek. Manjšalnici krühek in vüjček imata v slovarju pripisan še dodatni kvalifikator ljubkovalno.

Pomenotvornega nastanka sta narečno uveljavljeni sopomenki ficlek in frclek 'malenkost, delček', ki manjšalnega pomena ne pridobivata primerjalno s podstavnim samostalnikom, ampak v primerjavi s celoto, ter leksemi frtalek, ki manjšalni pomen pridobiva $\mathrm{v}$ odnosu do večjih (prostorninskih) enot, båtek, ki izraža mlado rastlino, ki zaradi svoje mladosti še ni dosegla končne velikosti, ter cirilek 'petelinček'. Skupino razširjajo še mezinček 'rman', kovaček 'ptiček stržek' in soldatek 'ciklama', ki kažejo metaforično asociacijo na osnovi videza oz. podobnosti.

Izglagolske tvorjenke tipa cecek 'sesek', natisek, süček niso manjšalnice, čeprav bi pri nekaterih od njih manjšalni pomen lahko motivirala ločitev dela od celote ali kratkotrajnost dejanja. V primerih špajzek 'shramba za živila', ta ima v narečju uveljavljeno sopomenko špajza in ne izkazuje sobesedilnih znakov za manjšalni pomen, lorbek in šnitlek, kjer gre za fonološko oz. morfološko prilagojeno različico nemških poimenovanj Lorbeer 'lovor' in Schnittlauch 'drobnjak', imajo pripone strukturalni, ne pa tudi besedotvorni pomen.

Drugo po tvorbeni rodnosti je obrazilo -ec. Dodaja se nepremenjeni podstavi: bingec 'majhna železna peč', drobec 'drobovina, navadno perutninska', korpec, lükec, pubec 'fantič', reklec 'jopica' (< rekla 'jopa'), žugec 'gosji mladič', ali po palatalizaciji premenjeni podstavi na $-k$ : rinčec. $\mathrm{V}$ primeru drobec manjšalni pomen motivira delnost $\mathrm{v}$ primerjavi s celoto, $\mathrm{v}$ primeru reklec pa je moškospolsko obrazilo -ec dodano ženskospolski podstavi.

Skupino razširjajo še ječmenec 'ječmenček', kačec 'kačji pastir' in ogjec 'ognjič', ki kažejo metaforično asociacijo na osnovi videza in so tako pomenotvornega nastanka. Izglagolska tvorjenka prdec ni manjšalnica, čeprav bi manjšalni 
pomen lahko motivirala kratkotrajnost dejanja, a le v semantičnem, ne pa tudi besedotvornem smislu. Vprimeru stolec 'stol' je v narečju prišlo do leksikalizacije.

Obrazilo -ič, ki je naglašeno in se dodaja glasovno nepremenjeni podstavi, tvori šest tvorjenk: čavlič 'krajši žebelj', jastrebič 'ptica ujeda, skobec', kokotič 'mlad petelin', lagvič, pejič 'manjši čok', žaklič. V primeru jastrebič se metaforična asociacija vzpostavlja na osnovi podobnosti med dvema živalma.

Manj rodno je obrazilo -c, izpričano pri tvorjenkah püšlc in štiblc. V primeru štinglc manjšalnega pomena iz pripisane knjižne ustreznice pecelj ni mogoče razbrati, navidezno pa se manjšalnicam pridružuje tudi gvirc, saj »gre za že glasoslovno prilagojeno različico nemškega poimenovanja gewürtz 'začimba' " (Merše 2010: 52).

Obrazilo -(i)č potrjuje primer $\operatorname{obl}(i) \check{c}$.

\subsubsection{Manjšalnice ženskega spola}

Obrazila manjšalnic ženskega spola si glede na tvorbeno rodnost padajoče sledijo v naslednjem zaporedju: -ica (bükvica), -ika (grolika), -ka (krnička), -ca (mrkevca) in -(in)-ka (štalinka). Obrazilo -ica se za množinske samostalnike realizira kot -ice (garice).

Najbolj rodno je obrazilo -ica, ki je (redko) lahko tudi naglašeno (goríca). Dodaja se glasovno nepremenjeni podstavi: bükvica 'mlada bukev', frajlica, gorica 'vinograd', gožvica 'krajša enoletna vrbova šiba', grabica 'del vinograda', hamica, hütica, jenkica, korpica, lesvica, rahlica 'manjša fižolovka' (< rahla 'fižolovka'), ribica, stopica 'manjša lesena stopa', šajbica, škrebl(i)ca 'ropotuljica', trütrica 'mala marjetica'. Jotacijsko premeno kaže primer koščica. Skupino razširjata še samostalnik vedrica z ženskospolskim obrazilom -ica, dodanim srednjespolski podstavi, in množinski samostalnik garice, izpeljan iz istospolnega nemanjšalnega množinskega samostalnika.

Pomenotvorno nastale besede so mišica 'mušica, majhni muhi podobna žuželka', ribica 'ledvica', sablica 'gladiola', mošnica 'strok', mašinica 'avtomatska puška', leksikalizacijo v narečju pa kažeta primera vdovica 'vdova' in metica 'meta'.

Drugo po pogostnosti pojavljanja je obrazilo -ika, ki se dodaja glasovno nepremenjeni podstavi: båbika 'punčka, dojenček', buhika, grolika, jarika 'mlada kokoš, mladika', mamika, puc(i)ka 'deklica', sirotika 'sirotica', ali palatalizacijsko premenjeni podstavi na -c: senčika 'senčica', tečika 'tetka' (< teca 'teta'), žganička 'žganjece'. Iz slovarja je razvidna tudi tvorba manjšalnic na -ika kot drugostopenjskih tvorjenk iz tvorjenih podstav na -ica: vej(n)čika. Manjšalnici mamika in žganjička imata v slovarju pripisan kvalifikator ljubkovalno.

Pomenotvorno nastala beseda je cirilika 'okrasna kokoška'.

Manj rodni sta obrazili $-k a$ in -ca; slednje je lahko nastalo tudi po redukciji iz -ica. Obrazilo - $k a$ se dodaja palatalizacijsko premenjeni podstavi na -c (krnička, untrčka) ali -k (kečka 'šop las' (<keka 'lasje')), z njim pa je izpeljana tudi dru- 
gostopenjska tvorjenka iz tvorjene podstave na -ica (sklečka). Pomenotvornega nastanka je beseda ritka 'škopa, snop urejene slame z debelejšim spodnjim delom', ki kaže metaforično asociacijo na osnovi širitve pomena.

Obrazilo - ca se dodaja glasovno nepremenjeni podstavi: rajnglca, mrkevca; v primeru vilce gre za izpeljavo z obrazilom -ce $(<-i c e)$ iz istospolnega nemanjšalnega množinskega samostalnika.

Obrazilo -(in)-ka izkazuje primer štalinka 'manjši (stranski) hlev', kjer manjšalni pomen motivira izražena majhnost oz. delnost v primerjavi s celoto.

\subsubsection{Manjšalnice srednjega spola}

$\mathrm{V}$ ormoškem govoru nastajajo srednjespolske manjšalnice z obrazili -ce (koritce, kolce), -e (krnče 'manjša, neješča svinja') in -(č)e (kravče, s pripisanim kvalifikatorjem slabšalno).

\section{IZLASTNOIMENSKE MANJŠALNICE V OBRAVNAVANIH SLOVARJIH}

V slovarskem delu obravnavanih prleških narečnih slovarjev je zajeto tudi lastnoimensko besedje. Osredotočili smo se na iztočnice z ženskimi in moškimi osebnimi imeni, tj. hipokoristične in deminutivne tvorjenke. Bogato, pogosto v sopomenskem nizu predstavljeno gradivo v GPA kaže, da se je manjšalno-ljubkovalni pomen moških imen na -ek, -ec, -c ali -č, npr. Anza in Anzek 'Janez', Drašek 'Andrej', Franček 'Franc', Jakec in Japek 'Jakob', Korl in Korlek 'Karel', Lenc in Lenček 'Lovrenc', Lujz in Lujzek 'Alojz', Tunč, Tunček in Tunek 'Anton', in ženskih imen na -ika, -ka, -ica, npr. Anika in Nanika 'Ana', Fefa in Fefika 'Genovefa', Jula, Julica in Julika 'Justina', Katica in Katika 'Katarina', Lunka 'Polona', Liza in Lizika 'Elizabeta', Mica in Micika 'Marija', Pepa in Pepika 'Jožefa', že izgubil.

V CB imajo nekatera moška in ženska imena pripisan kvalifikator, ki kaže na njihov manjšalno-ljubkovalni pomen. Ta se pri moških imenih najpogosteje izraža z obraziloma -ek in -ec, redkeje z -i (Arnek 'ljubk. Jernej', Drašek'ljubk. Andraž', Felček 'ljubk. Feliks', Južek 'ljubk. Jožef', Karlek 'ljubk. Karel', Vincek 'ljubk. Vincenc'; Jakec 'pomanjševalnica imena Jakob', Jürkec 'pomanjševalnica imena Jurij', Mihec 'ljubk. Mihael', Vinkec 'ljubk. Vincenc'; Pepi 'ljubk. Jožef'), pri ženskih imenih pa z obrazilom -ika (Barčika 'ljubk. Barbara', Evika 'ljubk. Eva', Fefika 'ljubk. Genovefa', Idika 'pomanjševalnica imena Ida', Karlika 'ljubk. žensko ime', Lizika 'ljubk. Elizabeta', Lujzika 'ljubk. Alojzija', Micika 'ljubk. Marija', Pepika, Zefika 'oboje ljubk. Jožefa', Tunčika 'ljubk. Antonija'), redkeje z obrazili -ka (Barčka 'ljubk. Barbara', Štefka 'ljubk. Štefanija'), -ica (Evica 'ljubk. Eva', Štefica 'ljubk. Štefanija') in -ca (Marjanca 'ljubk. žensko ime').

V ormoškem govoru se manjšalno-ljubkovalni pomen moških in ženskih imen izgublja. Pripis pri imenu Hanzek 'ljubkovalnica od Hanza' še kaže nanj, primera Štefek ‘Štefan' in Jürek 'Jurij’ pa ga ne izkazujeta več. Enako velja za ženska imena Micika 'Marija', Pepika s sopomenko Pepa 'Jožefa' in Štefica 'Štefanija'. 


\section{ZAKLJUČEK}

4.1 Skupina samostalnikov, izpeljanih s tipičnimi obrazili za izražanje manjšalnic, v prleškem narečju ni obsežna. Niz tovrstnih tvorjenk bi sicer lahko bil daljši, a kriterij razvrščanja je bilo preverjanje manjšalnostnega ali katerega od sorodnih pomenov (prim. Merše 2010: 45).

4.2.1 Najrodnejši moškospolski obrazili samostalniških manjšalnic v prleškem narečju sta $-e k$ in -ec.16 Prvo je najpogostejše tudi v Pleteršnikovem slovarju in v SSKJ, drugo pa je v SSKJ četrto, pri Pleteršniku pa drugo najrodnejše obrazilo (Stramljič Breznik 2008: 62). Morfem -ček, v sodobnem slovenskem knjižnem jeziku po rodnosti na drugem mestu (Stramljič Breznik 2008: 62), je v prleškem narečju veliko manj roden. $\mathrm{V}$ cerkvenjaškem govoru se manjšalnice $\mathrm{z}$ njim še tvorijo, $\mathrm{v}$ ormoškem govoru pa ni izpričan. Manj rodni obrazilni morfemi v prleščini so -ič, $-c$ in $-\check{c}$, najmanj produktivni priponski obrazili pa sta $-i c$ in -injak, izpričani le $\mathrm{v}$ cerkvenjaškem govoru. Primerjavo moškospolskih manjšalnic $\mathrm{v}$ obravnavanih slovarjih prikazuje preglednica 2.

\section{Preglednica 2: Primerjava moškospolskih manjšalnic v prleških narečnih slovarjih}

\begin{tabular}{|c|c|c|c|c|c|c|}
\hline $\begin{array}{l}\text { Pogostnostna } \\
\text { razvrstitev }\end{array}$ & GPA & $\begin{array}{l}\begin{array}{l}\text { Odstotni } \\
\text { delež }\end{array} \\
\end{array}$ & CB & $\begin{array}{l}\begin{array}{l}\text { Odstotni } \\
\text { delež }\end{array} \\
\end{array}$ & SSOG & $\begin{array}{l}\begin{array}{l}\text { Odstotni } \\
\text { delež }\end{array} \\
\end{array}$ \\
\hline 1 & -ek & 48,65 & -ek & 45,00 & -ek & 69,64 \\
\hline 2 & $-e c$ & 22,52 & $-e c$ & 26,66 & $-e c$ & 14,29 \\
\hline 3 & -ček & 14,42 & -ič & 13,33 & $-i c ̌$ & 10,71 \\
\hline 4 & $-i \check{c}$ & 6,31 & $-c$ & 10,00 & $-\mathrm{c}$ & 3,57 \\
\hline 5 & $-\mathrm{c}$ & 4,50 & $-i c$ & 1,67 & $-c \check{c}$ & 1,79 \\
\hline 6 & $-\underline{c}$ & 2,70 & $-\check{c}$ & 1,67 & & \\
\hline 7 & -(in)-jak & 0,90 & -(in)-jak & 1,67 & & \\
\hline
\end{tabular}

4.2.2 Najrodnejše ženskospolsko obrazilo samostalniških manjšalnic v prleškem narečju je -ica, ki je najpogostejše tudi v Pleteršnikovem slovarju in SSKJ (Stramljič Breznik 2008: 65),17 kot najbolj rodno pa ga izkazuje tudi prekmurščina (Koletnik 2015: 462). V cerkvenjaškem govoru mu sledi obrazilo - $c a$, tretje najrodnejše obrazilo pri Pleteršniku in v SSKJ, v ormoškem pa -ika, ki je pri Pleteršniku četrto najrodnejše obrazilo, v sodobnem slovenskem knjižnem jeziku pa ženskospolske manjšalnice z njim ne nastajajo več. V prekmurščini, pri Pleteršniku in v SSKJ drugo najrodnejše obrazilo -ka kot nekoliko manj rodno potrjuje tudi prleščina. Samo narečni, najmanj rodni besedotvorni morfemi so -(in)-ka, -ačka in -arka/-orka. Teh priponskih obrazil prekmurščina ne izkazuje.

16 Enako je tudi v prekmurščini (Koletnik 2015: 461).

17 O priponskem obrazilu -ica je pisala tudi Mojca Horvat (2013: 33-57). 
Preglednica 3: Primerjava ženskospolskih manjšalnic v prleških narečnih slovarjih

\begin{tabular}{|c|c|c|c|c|c|c|}
\hline $\begin{array}{l}\text { Pogostnostna } \\
\text { razvrstitev } \\
\end{array}$ & GPA & $\begin{array}{l}\text { Odstotni } \\
\text { delež }\end{array}$ & CB & $\begin{array}{l}\text { Odstotni } \\
\text { delež }\end{array}$ & SSOG & $\begin{array}{l}\text { Odstotni } \\
\text { delež }\end{array}$ \\
\hline 1 & -ica & 32,23 & -ica & 44,44 & -ica & 50,00 \\
\hline 2 & $-\mathrm{ca}$ & 27,27 & $-\mathrm{ca}$ & 31,75 & -ika & 28,94 \\
\hline 3 & -ika & 23,14 & $-\mathrm{ka}$ & 11,11 & $-\mathrm{ka}$ & 10,53 \\
\hline 4 & $-\mathrm{ka}$ & 16,53 & $-\mathrm{ika}$ & 7,94 & -ca & 7,90 \\
\hline 5 & -(in)-ka & 0,83 & -ačka & 1,59 & -(in)-ka & 2,63 \\
\hline 6 & & & -arka/-orka & 3,17 & & \\
\hline
\end{tabular}

4.2.3 Srednjespolske manjšalnice, ki jih je v prleškem narečju najmanj, se v cerkvenjaškem govoru največkrat tvorijo $\mathrm{z}$ obrazilom $-e, \mathrm{v}$ ormoškem pa $\mathrm{z}$ obrazilom $-c e$, ki je kot najrodnejše izpričano tudi v Pleteršnikovem slovarju in SSKJ (Stramljič Breznik 2008: 67); -ce kot najrodnejše manjšalno srednjespolsko obrazilo izkazuje tudi prekmurščina (Koletnik 2015: 462). V prleščini je potrjeno tudi sodobno knjižno obrazilo -(̌̌) e. Cerkvenjaški govor potrjuje še srednjespolsko obrazilo -ca, ki se druži z ženskospolskimi množinskimi samostalniki.

Preglednica 4: Primerjava srednjespolskih manjšalnic v prleških narečnih slovarjih

\begin{tabular}{|c|c|c|c|c|c|c|}
\hline $\begin{array}{l}\text { Pogostnostna } \\
\text { razvrstitev }\end{array}$ & GPA & $\begin{array}{l}\text { Odstotni } \\
\text { delež }\end{array}$ & CB & $\begin{array}{l}\text { Odstotni } \\
\text { delež }\end{array}$ & SSOG & $\begin{array}{l}\text { Odstotni } \\
\text { delež }\end{array}$ \\
\hline 1 & $-e$ & 62,50 & $-e$ & 75,0 & -ce & 50,0 \\
\hline 2 & -ca & 12,50 & $-(\check{c}) \mathrm{e}$ & 25,0 & $-\mathrm{e}$ & 25,0 \\
\hline 3 & -(̌c)e & 12,50 & & & 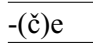 & 25,0 \\
\hline 4 & -ce & 12,50 & & & & \\
\hline
\end{tabular}

4.3 V prleškem narečju je s samostalniškimi manjšalnicami najpogosteje izražena majhnost oz. majhen obseg ali delnost česa, izražena so mlada bitja ter prisrčen odnos oz. naklonjenost do živih bitij, kar z manjšalno-ljubkovalnimi obrazili potrjujejo tudi izlastnoimenske tvorjenke v Cerkvenjaškem besednjaku. Pri manjšalnicah $\mathrm{z}$ razvito polisemijo, ki jo najpogosteje razvijejo ženskospolske manjšalnice na -ica in $-c a(<-i c a)$ ter moškospolske manjšalnice na -ek, se sekundarni pomen najpogosteje razvije zaradi metaforičnega prenosa na osnovi videza ali oblike, npr. iglica, kopica, malinca, preslca, sablica; čolniček, ječmenček, mezinček, sirek. Pri omenjenih ženskospolskih manjšalnicah je najpogostejša tudi leksikalizacija, npr. greblca, metica, tetica, vdovica. 


\section{VIRI IN LITERATURA}

Bajec 1950 = Anton Bajec, Besedotvorje slovenskega jezika 1: izpeljava samostalnikov, Ljubljana: SAZU, 1950.

CB $\rightarrow$ Paluc 2010

DLS = Hildegard Striedter Temps, Deutsche Lehnwörter im Slovenischen, Berlin: Osteuropa-Institut, 1963.

Dragićević 2015 = Rajna Dragičevič, Nedeminutivnye značenija deminutitov, v: Manjšalnice v slovanskih jezikih: oblika in vloga, ur. Irena Stramljič Breznik, Maribor: Mednarodna založba Oddelka za slovanske jezike in književnosti, Filozofska fakulteta, 2015 (Mednarodna knjižna zbirka Zora 113), 88-101.

ESSJ 1-2 = France Bezlaj, Etimološki slovar slovenskega jezika 1-2: A-J, K-O, Ljubljana: Mladinska knjiga, 1976.

\section{GPA $\rightarrow$ Rajh 2010}

Hajnšek Holz 1999 = Milena Hajnšek Holz, Lastna imena v Murkovem slovarju, v: Murkov zbornik, ur. Marko Jesenšek, Maribor: Slavistično društvo, 1999 (Zora 9), 292-303.

Horvat 2013 = Mojca Horvat, Narečne tvorjenke s priponskim obrazilom -ica iz pomenskega polja »človek« (po gradivu za SLA 1), Dialektološki razgledi = Jezikoslovni zapiski 19 (2013), št. $2,33-57$.

Keber 2001 = Janez Keber, Leksikon imen, Celje: Mohorjeva družba, 1999.

Keber 2001a = Janez Keber, O strukturi rojstnih imen v Sloveniji, Jezikoslovni zapiski 7 (2001), št. $1-2,21-112$.

Keber 2002 = Janez Keber, Rojstna imena, hišna imena, vzdevki, psevdonimi v Sloveniji, Jezikoslovni zapiski 8 (2002), št. 2, 47-70.

Koletnik 2008 = Mihaela Koletnik, Panonsko lončarsko in kmetijsko izrazje ter druge dialektološke razprave, Maribor: Mednarodna založba Oddelka za slovanske jezike in književnosti, Filozofska fakulteta, 2008 (Mednarodna knjižna zbirka Zora 60).

Koletnik 2015 = Mihaela Koletnik, Samostalniške manjšalnice v prekmurskih narečnih slovarjih, v: Manjšalnice v slovanskih jezikih: oblika in vloga, ur. Irena Stramljič Breznik, Maribor: Mednarodna založba Oddelka za slovanske jezike in književnosti, Filozofska fakulteta, 2015 (Mednarodna knjižna zbirka Zora 113), 450-464.

Merše 2010 = Majda Merše, Raba samostalniških manjšalnic v delih slovenskih protestantskih piscev 16. stoletja, Slavistična revija 58 (2010), št. 1, 45-63.

Paluc $2010=\mathbf{C B}=$ Ciril Paluc, Cerkvenjaški besednjak - Antujoški besednjak, Maribor: Umetniški kabinet Primož Premzl, 2010.

Pleteršnik 2006 = Maks Pleteršnik, Slovensko-nemški slovar (1894-1895): transliterirana izdaja, ur. Metka Furlan, Ljubljana: Založba ZRC, ZRC SAZU, 2006.

Rajh 2010 = GPA= Bernard Rajh, Gúčati po antùjoško, Maribor: Mednarodna založba Oddelka za slovanske jezike in književnosti, Filozofska fakulteta, 2010 (Mednarodna knjižna zbirka Zora 73).

Snoj 2003 = Marko Snoj, Slovenski etimološki slovar, Ljubljana: Modrijan, 2003.

SSKJ = Slovar slovenskega knjižnega jezika, Ljubljana: SAZU, ZRC SAZU (izd.) - Državna založba Slovenije (zal.), 1995.

\section{SSOG $\rightarrow$ Vnuk 2010}

Stramljič Breznik 1999 = Irena Stramljič Breznik, Prispevki iz slovenskega besedoslovja, Maribor: Slavistično društvo, 1999 (Zora 7).

Stramljič Breznik 2004 = Irena Stramljič Breznik, Besednodružinski slovar slovenskega jezika: poskusni zvezek za iztočnice na B, Maribor: Slavistično društvo, 2004 (Zora, Priročniki 1).

Stramljič Breznik 2008 = Irena Stramljič Breznik, Besedotvorna kategorija samostalniških manjšalnic v Pleteršnikovem slovarju in SSKJ, v: Od Megiserja do elektronske izdaje Pleteršnikovega slovarja, ur. Marko Jesenšek, Maribor: Filozofska fakulteta, Oddelek za slovanske jezike in književnosti, 2008 (Zora 56), 56-68.

Valh Lopert 2015 = Alenka Valh Lopert, Manjšalnice v terminološkem gnezdu Slovarja slovenskega knjižnega jezika² $\left(\mathrm{SSKJ}^{2}\right)$, v: Manjšalnice v slovanskih jezikih: oblika in vloga, ur. Irena 
Stramljič Breznik, Maribor: Mednarodna založba Oddelka za slovanske jezike in književnosti, Filozofska fakulteta, 2015 (Mednarodna knjižna zbirka Zora 113), 598-611.

Vidovič Muha 1988 = Ada Vidovič Muha, Slovensko skladenjsko besedotvorje ob primerih zloženk, Ljubljana: Znanstveni inštitut Filozofske fakultete, 1988.

Toporišič 1992 = Jože Toporišič, Enciklopedija slovenskega jezika, Ljubljana: Cankarjeva založba, 1992 (Leksikoni Cankarjeve založbe, Zbirka Sopotnik).

Toporišič $\mathbf{2 0 0 0}$ = Jože Toporišič, Slovenska slovnica, Maribor: Obzorja, 2000.

Vnuk 2012 = SSOG = Ciril Vnuk, Slovar severovzhodnega ormoškega govora s kratkim opisom, Ormož: Zgodovinsko društvo, 2012.

Weiss 1998 = Peter Weiss, Slovar govorov Zadrečke doline med Gornjim gradom in Nazarjami, Ljubljana: ZRC SAZU, Založba ZRC, 1998 (Slovarji).

\section{SUMMARY}

\section{Nominal Diminutives in Prlekija Dialect Dictionaries}

This article describes the scope of nominal diminutives (i.e., modification word formations) in three Prlekija dialect dictionaries: Gúčati po antùjoško (The Cerkvenjak Dialect; Bernard Rajh, 2010), Cerkvenjaški besednjak - Antujoški besednjak (Cerkvenjak Vocabulary; Ciril Paluc, 2010), and Slovar severovzhodnega ormoškega govora s kratkim opisom (Dictionary of the Northeast Ormož Dialect with a Brief Description; Ciril Vnuk, 2012). It compares them in terms of productivity and the classification characteristics of word-formation affixes. The article determines that there are no significant differences in derivational diversity between masculine and feminine diminutives, whereas neuter diminutives are derivationally less diverse. The most productive masculine ending for nominal diminutives in the Prlekija dialect is -ek (e.g., kolaček 'little cake') and -ec (e.g., cvekec 'little nail'). The morpheme -ček, which ranks second in productivity in modern standard Slovenian, still produces diminutives in the Cerkvenjak subdialect (e.g., čebrček 'little tub'), but this is not confirmed in the Ormož subdialect. The most productive feminine ending for nominal diminutives is -ica (e.g., kantica 'little can'), followed in the Cerkvenjak subdialect by the ending - $c a$ (e.g., sekirca 'hatchet') and -ika in the Ormož subdialect (e.g., sirotika 'little orphan'), which no longer produces feminine diminutives in modern standard Slovenian. Neuter diminutives, of which there are the fewest in the Prlekija dialect, are usually created in the Cerkvenjak subdialect with the ending -e (e.g., prase 'piglet') and in the Ormož subdialect with the ending -ce (e.g., koritce 'little trough'). The Prlekija dialect also has the modern standard ending -(č)e (e.g., kravče 'little cow') and the endings -ca (e.g., dverca 'little door') and -je (e.g., mladje 'young woods'). In diminutives with developed polysemy, which is most frequent for feminine diminutives in -ica and -ca, and masculine diminutives in $-e k$, the secondary meaning most often develops due to metaphorical transfer based on appearance or shape (e.g., malinca 'mulberry', sablica 'iris'; ječmenček 'stye'). For feminine diminutives in -ica and -ca, the most frequent is semantic lexicalization (e.g., greblca 'mason's level', tetica 'older woman', vdovica 'widow'). In the Prlekija dialect, nominal diminutives most often express smallness, a small scope, or a part of something, young beings, and an affectionate relationship or inclination towards living beings, which is also confirmed by derivatives formed from proper nouns with diminutive/affectionate endings in Cerkvenjaški besednjak. 